\title{
IZAZOVI TRANSFUZIJSKE MEDICINE DANAS I SUTRA
}

JUKIĆ $1 ., 2$

${ }^{1}$ Hrvatski zavod za transfuzijsku medicinu

${ }^{2}$ Medicinski fakultet, Sveučilište Josipa Jurja Strossmayera u Osijeku

Prije dvadeset i jednog mjeseca zbunjujuća situacija ispred Hrvatskog zavoda za transfuzijsku medicinu, neposredno prije početka radnog vremena. Sukladno preporuci epidemiologa upućujemo doma dvoje djelatnika koji su na akciji darivanja krvi bili u izravnom kontaktu s prvim hospitaliziranim bolesnikom koji je imao PCR pozitivan test na SARS-CoV 2 virus. Do tada smo svi uglavnom imali manje-više nedostatne informacije o novom kineskom virusu koji se širi od Azije prema Europi preko Italije. Naš potencijalni darivatelj, mlad čovjek bez ikakvih zdravstvenih tegoba odgođen je zbog boravka u Italiji nekoliko dana prije odvijanja akcije. Epidemiolozi Hrvatskog zavoda za javno zdravstvo izuzetno brzo i učinkovito detektiraju kontakte svih darivatelja i naše terenske ekipe i u dogovoru s njima šaljemo naših dvoje djelatnika u samoizolaciju. I, to jutro je hrvatska transfuzijska služba ušla u novu fazu rada, razmišljanja, ponašanja,..., ušla u neke nove izazove i počela strahovati prvenstveno glede sigurnosti transfuzijskog liječenja. Slijedilo je pretraživanje svih objavljenih radova i iskustava iz cijelog svijeta (hvala Bogu na Google-u), slijedili su on-line sastanci s kolegama iz Europe, slijedila je hiperprodukcija dokumentacije, od definiranja i osnivanja Kriznih stožera u ovlaštenim zdravstvenim ustanovama do Smjernica, Preporuka,... Najbolji pokazatelj intenziteta rada jest pet revizija jednog dokumenta unutar manje od godine dana dok nam je u nekim ranijim normalnim vremenima za neku promjenu trebalo cijelo desetljeće.

U proteklih dvadeset i jedan mjesec promijenili su se svima nama brojni segmenti života, a našoj struci su postavljena brojna nova pravila kojima se mi transfuziolozi, poznato disciplinirana medicinska grana, vrlo brzo prilagođavamo. Povezujemo sveukupno pučanstvo preko davalaštva krvi i taj naš javnozdravstveni dio je uglavnom najviše pogođen epidemijskim teškoćama. Kolateralna smo žrtva epidemije ponajviše glede zaliha krvnih pripravaka. Oscilacije zaliha i zahtjeva su u jednom trenutku bile nezapamćeno inverzne jer nitko u transfuzijskoj povijesti ne pamti da je bila veća potreba za brojem koncentrata trombocita nego za brojem koncentrata eritrocita, a onda nagle promjene nakon otvaranja bolnica i deficit od kojeg se teško oporavljamo mjesecima. Organizacija akcija prikupljanja krvi je postala mučan i neizvjestan posao bez obzira na količinu uloženog truda. Izolacije, samoizolacije naših redovitih i potencijalnih darivatelja krvi, rad od doma, nemogućnost organiziranja akcija u nekim ustanovama i firmama su značajno utjecali i još uvijek utječu na stanje zaliha krvnih pripravaka. $\mathrm{Za}$ dodatnu začudnu dinamiku pobrinuli su se i potresi, prirodna katastrofa koja je ponovo pokazala veliko hrvatsko srce. Redovi strpljivih ljudi satima su na hladnoći, u skladu sa epidemiološkim mjerama, čekali na iskaz svoje humanosti. To je privilegija rada u ovom dijelu transfuzijske medicine - doticaj s čistom ljudskom dobrotom. Napunili smo hladnjake u cijeloj Hrvatskoj, pokazali kako izvrsno funkcionira krvotok solidarnosti, kako smo mi struka koja solidarno reagira bez naputaka nadređenih institucija. Prijelaz iz stare, grozne, teške, naporne 2020. godine u duhu plemenitosti željeli smo protumačiti upravo kao optimizam i nadu kako će nam nadolazeća 2021. godina biti normalna, kako ćemo sve „muke po koroni“ ostaviti iza sebe. Tom optimizmu je dodatno pogodovao početak cijepljenja. Unatoč svemu, stiže treći val i svi naši raniji problemi se ponavljaju i traju i traju i traju

Početkom lipnja prošle godine, istovremeno kada i razvijene europske zemlje uvodimo i proizvodnju novog krvnog pripravka - konvalescentnu plazmu koja je osim izravne pomoći transfundiranja bolesnicima značajno pomaže i u destigmatizaciji osoba koje su preboljele COVID-19, poglavito na samom početku kada su ih drugi sugrađani doživljavali na različite načine. Dugo vremena je prošlo dok su naši kliničari započeli primjenu iste bolesnicima, a onda je krenula velika potražnja jer je nekim bolesnicima koji su je dobili u pravom trenutku došlo do vidljivog poboljšanja. Pomoć pri oporavku bar jedne oboljele osobe opravdava sav uloženi trud, a kolege sa nekih klinika svjedoče o puno većem broju bolesnika kod kojih se bilježilo poboljšanje. Bilo je jedno vrijeme zatišje u narudžbama konvalescentne plazme, ali zadnjih dana je ponovo aktualna, što je svakako odraz stanja tijekom ovog četvrtog vala.

Korona tema će biti nezaobilazna tijekom našeg kongresa kao što je nezaobilazna u našoj i stručnoj i privatnoj svakodnevnici. Uz sve muke glede organizacije rada, smanjenih zaliha, brojnih poslijedonacijskih informacija,... možemo biti sretni i Bogu zahvalni što nas je u ovom hororu zaobišao problem kojeg smo se u početku najviše bojali - prijenos SARS-CoV 2 virusa krvnim pripravcima. Nigdje, ni u jednom znanstvenom radu nije objavljen potvrđeni prijenos, čak niti kod praćenja hematoonkoloških bolesnika transfuzijski liječenih krvnim 
pripravcima priređenim od darivatelja koji su bili asimptomatski u fazi inkubacije u trenutku darivanja krvi. Ovo je zaista jedna od rijetkih virusnih infekcija za koju nema dokaza da je krvlju prenosiva. U protivnom bi to bilo potpuno gašenje naše grane medicine, a posljedično i gašenje brojnih života.

Očito nam još nije suđeno vrijeme nestajanja, još puno toga mi moramo odraditi iako ponekad mislimo kako smo daleko došli. Malo nam pomogne znanstvena znatiželja, malo napredak tehnologije, ponekad slučajni događaji, ali sumarno se ipak krećemo naprijed, iako stalno prigovaramo brzini tog kretanja. Samokritički bi mogli definirati puno slabih točaka kako nas pojedinaca, tako i cjelovitog našeg stručnog Društva koje bi moglo i moralo bolje. Nužno je uključivanje mladih kolegica i kolega spremnih na davanje i realizaciju ideja, spremnih na nove aktivnosti, ali i preuzimanje odgovornosti, spremnih na kritike postojećeg stanja, ali i nuđenje alternativnih rješenja. Vrata su otvorena, samo ulazite i ne zatvarajte ih za sobom jer će možda još netko stidljivo zakucati. Transfuzijska medicina nije niti može biti nikakva zabarikadirana utvrda, niti prostor dominacije nekog pojedinca ili privilegirane skupine samozvanih stručnjaka. Naprotiv, najotvorenija je grana medicine jer „dotikavlje“ sve, povezuje sve, od zdravih do bolesnih, od darivatelja do primatelja, ona je most između dobrote i iščekivanja, dio medicine koji dar plemenitog čovjeka prerađuje u lijek za nemoćnog bolesnika. Najvažnija je činjenica da nema jasne granice pripadnosti između darivatelja i primatelja krvi u jednom narodu osim što je svatko od nas u svakom trenutku svog života potencijalni primatelj, a broj potencijalnih darivatelja je ipak ograničen.

Nakon što smo transfuzijsku službu uglavnom reorganizirali i okrupnili, nakon što smo se uglavnom informatički povezali, nakon što smo se više-manje standardizirali u radu i opremi, nakon što smo svojim radom i rezultatima postali prepoznatljivi dio razvijenog svijeta, slijede prepoznavanja područja za poboljšanje i stalni rad na unaprjeđenju u svim segmentima transfuzijske medicine. To je otvorena platforma za sve naše mlade snage ako imaju želju, ako imaju inicijativu i volju. Temelji su poprilično čvrsti i nikada nemojte posustati jer će o vama i samo o vama zavisiti i vaš i status naše i vaše struke. Znanje je najbolji alat i najjače oružje, a možda niti u jednoj grani medicine nije tako široka platforma istraživanja i tako velika mogućnost suradnje sa drugim strukama. Tu prednost morate prepoznati i na njoj graditi budućnost jer je naša struka jedina „bankarska“ struka u medicini. Gledajući banke kao uspješnice u ekonomskom smislu i bankare kao najuspješnije (?) ljude, za nas nema straha. Možda klasični bankari nikada ne bi postali baš najbogatiji da su bili stalno podvrgnuti kontrolama kao što su svi postupci u našoj struci. U konačnici, i njima se pojavila neželjena virtualna konkurencija jer na svjetskom financijskom tržištu kriptovalute polako ali nezaustavljivo uzimaju dio bankarskog monopolističkog prostora. Naše krvne i tkivne banke nisu temeljene na istim motivima, nisu vođene profitom i to je ključna razlika od ovih drugih, a naši bankari nisu financijski nego transfuzijski stručnjaci. Dok nas vodi stručna i znanstvena znatiželja ne bojimo se nikakvih konkurencija, a nove ideje i nova postignuća su uvijek dobro došla svakom otvorenom umu. Naša struka je uvijek bila i ostaje otvorena za suradnju na svim relacijama, za prihvaćanje novih ideja, tehnologija, znanstvenih dostignuća, za razmjenu znanja i iskustva. Internetska komunikacija daje nam svima mogućnost konzultacija, mogućnost bržeg rješavanja nekih problema i mogućnost ujednačavanja rada. Posebna je to prednost za mlade kolege koji se ne trebaju bojati za budućnost transfuzijske medicine bez obzira u kojem gradu radili i kojim se dijelom transfuzijske medicine profesionalno bavili. Ako imate želju za znanjem, svi su vam putevi otvoreni!

Teško je prognozirati što nas sve čeka i s kojima ćemo se problemima susretati jer je ovaj „mali“, nevidljivi virus izazvao veliku pandemija i pokazao kako smo mali, malešni, sitni bez obzira što o sebi mislili i kako nas drugi doživljavali. Preraspodijelio nam je prioritete, okrenuo nas naglavačke, a mi smo se resetirali i nastavili raditi na najbolji mogući način u postojećim okolnostima. Možda smo mogli bolje jer uvijek može bolje, možda bi netko drugačije. Mi smo se maksimalno angažirali i znanjem i srcem kao i tijekom Domovinskog rata. Zahvalni smo i dežurnim kritičarima jer bi bez njih bilo nezanimljivo. Ponekad nam daju i dodatni poticaj. Svaka kritika je dobro došla, poglavito ako nudi i konkretne prijedloge. Za prazne kritike nemamo vremena.

Transfuzijska medicina kao javnozdravstvena struka je uvijek bila i biti će pod povećalom javnosti. I to je dio našeg rada unutar kojeg moramo uvijek biti dosljedni i vođeni samo i isključivo znanjem temeljenim na dokazima i, neizostavno, etičkim načelima. Mora nas voditi spoznaja kako su lijekovi koje proizvodimo biološkog podrijetla sa svim promjenjivim specifičnostima koje darivatelj nosi i koje samo djelomično možemo detektirati. Na drugoj strani je bolesnik primatelj kojem želimo i trebamo pomoći uz najmanji mogući rizik. Unatoč pridržavanju svih propisanih postupaka, unatoč suvremenim tehnološkim dostignućima, unatoč našem znanju i iskustvu, taj rizik se smanjuje, ali nikada neće potpuno nestati. Naša zadaća je i dalje smanjivati sve prepoznate rizike, dosljedno komunicirati sa javnošću i dalje raditi s nadom da će neki učinkoviti „kriptopripravci“ biti što prije široko dostupni. Puno ih je do sada bilo, od eritropoetina koji je zauzeo zasluženo mjesto u terapiji, trombopoetina koji to nije uspio, do potentnog hemoglobina dobivenog od pješčanog crva čija je uspješna primjena započeta u transportu organa za transplantaciju. Ipak, još dugo vremena nama će središnji izvor i dalje ostati darovane žive stanice zdravog čovjeka, možda zbog mističnog čimbenika kojeg nose u sebi, a koji se jednostavno zove život. 